\section{Between prison and the community}

\section{The 'revolving door psychiatric patient' of the nineties}

\author{
LUKE BIRMINGHAM
}

According to Torrey (1995), de-institutionalisation of the seriously mentally ill in America has been the largest failed social experiment of the 20th century. Many have failed to survive in the community because of inadequate after-care, and America's prisons and jails have slowly replaced mental hospitals as the primary provider of institutional care for the mentally ill. Estimates suggest that on any given day there are now twice as many seriously mentally ill individuals in prison as in state mental hospitals.

Evidence is now emerging that indicates that the closure of psychiatric hospitals coupled with under-resourced community care is causing a similar problem in Britain. Furthermore, it would seem that our prisons are acting as little more than temporary accommodation for the mentally ill, who are liable to remain undetected in prison and return to the community without treatment or psychiatric after-care.

Mental health services in Britain, especially those in inner-city areas, are in crisis (Marshall, 1997; Shepherd et al, 1997). If psychiatric services cannot respond to the needs of the seriously mentally ill in the community, individuals with troublesome or dangerous behaviour are likely to be dealt with by the criminal justice system. Teplin (1984) has shown that in similar circumstances, people with mental disorders are more likely to be arrested than their non-mentally disordered counterparts. The probability of remand into custody is also greater: those who commit violent acts are perceived as being more dangerous simply by virtue of having mental illness, and even when offending is of a less serious nature, the presence of mental illness increases the likelihood of remand (Taylor \& Gunn, 1984).

Court diversion services often experience an uphill struggle when faced with a mentally ill person in custody. Overstretched general psychiatric services may be unable or unwilling to help, a forensic bed is not usually an option, and even if a psychiatric disposal can be offered, the magistrate may refuse to accept this (Rowlands et al, 1996). Therefore, it is not surprising that research has shown that one in 20 men entering prison on remand is suffering from a psychosis (Birmingham et al, 1996).

Research by Gunn et al (1991) on male sentenced prisoners, together with that by Brooke et al (1996) on male remand prisoners, suggests that prisons in England and Wales contain more than 1000 men suffering from psychosis and nearly 2000 male prisoners who need treatment in psychiatric hospitals. The report on the prevalence of psychiatric morbidity among prisoners in England and Wales, published in October 1998 by the Office for National Statistics, paints an even bleaker picture. This largescale study reports that $7 \%$ of male sentenced and $10 \%$ of male remand prisoners suffer from functional psychotic disorders. If these findings are generalised to the prison population as a whole, this indicates that there are in excess of 4500 men with psychotic disorders in prison at the present time. Of course, prisoners with serious mental illness represent only the tip of the iceberg of psychiatric morbidity. There are many more prisoners who suffer from less severe forms of mental disorder, who do not require transfer to a psychiatric hospital, but who would none the less benefit from psychiatric treatment given in the prison setting.

Prisons were never intended to accommodate such a large health care burden and they are ill-equipped to do so. Prison reception health screening often fails to identify psychiatric morbidity (Mitchison et al, 1994; Birmingham et al, 1996, 1997) and mental illness frequently remains undetected during remand (Birmingham et al, 1998). When psychiatric treatment needs are identified, the response of the system is inefficient. A number of prisoners who are potential candidates for hospital treatment are rejected by consultant psychiatrists because they are perceived as being too disturbed or dangerous, or are seen as criminals who are unsuitable for treatment (Coid, 1988). Poor communication between prison, court and hospital systems hinders the assessment and management of mentally disordered offenders, and medical intervention can actually delay their release from custody (Robertson et al, 1994). When communication breaks down altogether, the result can be a sudden and unpredicted release of prisoners with acute psychosis who are then lost to follow-up in the community. However, many mentally ill prisoners receive no treatment or aftercare when they are released because their treatment needs are not recognised (Birmingham et al, 1998; Dell et al, 1993).

Once back in the community, mentally disordered offenders are unlikely to prove popular patients with general practitioners and psychiatrists. Those with a serious mental illness who do engage with health services may have additional problems such as comorbid substance misuse, and may comply poorly with treatment. Without assertive follow-up these patients are particularly prone to losing contact with services. Those who are in poor mental health, and who fall outside the umbrella of psychiatric services, are particularly prone to re-offend. Once this happens the cycle, starting with remand into custody, is likely to begin again.

\section{REFERENCES}

Birmingham, L., Mason, D. \& Grubin, D. (1996)

Prevalence of mental disorder in remand prisoners: consecutive case study. British Medical Journal, 313. $1521-1524$.

_, - \& - (1977) Health screening at first reception into prison. Journol of Forensic Psychiotry, 8 435-439.

-, - \& (1996) A follow-up study of mentally disordered men remanded to prison. Criminol Behoviour and Mental Heolth, 8, 202-213.

Brooke, D., Taylor, C., Gunn, J., et al (1996) Point prevalence of mental disorder in unconvicted male prisoners in England and Wales. British Medicol fournol, 313, $1524-1527$.

Coid, J. (1988) Mentally abnormal prisoners on remand: 1 - Rejected or accepted by the NHS? British Medical Journol, 296, 1779-1782

Dell, S., Robertson, G., James, K., ex al (1993) Remands and psychiatric assessments in Holloway Prison. I: The psychotic population. British journal of Psychiotry, 163, 634-640.

Gunn, J., Maden, A. \& Swinton, M. (1991) Treatment needs of prisoners with psychiatric disorders. British Medical fournal. 303. 338-341.

Marshall, M. (1997) London's mental health services in crisis. British Medical Journal, 314, 262.

Mitchizon, S., Rix, K., Reirroize, E., et al (1994) Recorded psychiatric morbidity in a large prison for male remanded and sentenced prisoners. Medicine Science and the Low, 34, 324-330. 
Ofice for National Statistics (1998) Psychiotric Morbidity Among Prisoners in England and Wales. London: HMSO.

Robertson, G., Dell, S., James, K., et of (1994) Psychotic men remanded in custody to Brixton Prison. British fournal of Psychiatry, 164,

$55-61$.

Rowlands, R., Inch, H., Roger, W., et ol (I996) Diver ted to where? What happens to the diverted mentally disordered offender? Journal of Forensic Psychiatry, 7, 284-296.

Shepherd, G., Beadamoore, A., Moore, C., of of

(1997) Relation between bed use. social deprivation and

overall bed availability in acute adult psychiatric units,

LUKE BIRMINGHAM, MRCPsych, Reaside Clinic, Birmingham Great Park, Bristol Road South, Birmingham B45 9BE. Fax: 0121-453-7181

(First received 20 October 1998, accepted 4 December 1998)

and alternative residential options: a cross sectional survey, one day census data, and staff interviews. British Medical journol, 314, 262.

Taylor, P. J. Gunn, J. (1984) Violence and psychosis: I - Risk of violence among psychotic men. British Medicol journol, 288. 1945 1949.
Teplin, L. (1984) Criminalising mental disorder. Americon Psychologist, 39, 794-803.

Torrey, E. (1995) Jails and prisons - America's new mental hospitals. Americon journol of Public Heolth, 85, 1611-1613. 